短 報

\section{尿中馬尿酸・ $\boldsymbol{m}$-メチル馬尿酸の高速液 体クロマトグラフィーによる定量}

\section{Quantitative Determination of Urinary Hippuric Acid and $m$-Methylhippuric Acid by High Performance Liquid Chromatography}

尿中の馬尿酸 $(\mathrm{HA}), m$-メチル馬尿酸 $(m-\mathrm{MHA})$ の定量により, toluene, $m$-xylene の平均吸入量を推定 する試みが広く行なわれてきた。

直接比色定量法1) はきわめて簡便であるが，同様な反 応を呈する尿中物質の影響を考虑する必要があり，之く 飞 HA と $m$-MHA が混在する尿はこの方法では分別 定量できない，そこで，各種のクロマトグラフィーを用 いて，尿中 glycine 抱合物の分離定量をする試み ${ }^{2}$ がな されている.

今回, 高速液体クロマトグラフィー (HLC) を用いて, 尿中 HA, $m$-MHA の分離定量を検討した結果，尿洔 別な前処理を行ならことなく，両者を分離定量できた。

\section{方 法}

1. 試料：HA は Merck, $m$-MHA, $p$-MHA は東京 化成, isonicotinuric acid (INA), salicyluric acid (SA) は日本感光色素研究所の製品を用いた。被験尿には, 健 康人 (正常尿)，および toluene, $m$-xylene 混合気体 (toluene $67 \mathrm{ppm}, m$-xylene $83 \mathrm{ppm}$ ) 飞 3 時間暴露後 2.5 時間後に採取した尿（暴露尿）を用いた.

2. 方法: 各 glycine 抱合物を移動相の液に溶かし 標準液とした，尿は遠心分離（1,500 rpm，5 min）した 後の上澄液をとのまま HLC に注入した，分析装置：高 速液体クロマトグラフィー 633 型（日立）, 充填剤 $: \mathrm{Li}$ Chrosorb RP 18, $10 \mu$ (Merck), カラム: $4.0 \mathrm{~mm} \phi$ $\times 150 \mathrm{~mm}$, カラム温度: 室温 (約 $25^{\circ} \mathrm{C}$ ), 移動相： methanol/水/酢酸 $(20 / 80 / 0.2)$, 流量: $1.2 \mathrm{ml} / \mathrm{min}$, 圧 力: $50 \mathrm{~kg} / \mathrm{cm}^{2}$, 検出器 : UV $254 \mathrm{~nm}$, 感度 : $0.08 \mathrm{AU}$ FS.

\section{結果と考察}

1. HA， $m$-HHA の分離 : 種々の glycine 抱合物溶 液を混合した液のクロマトグラムをFig. 1 に示す。 HA，o-MHA， $m$-MHA あるいは $p$-MHA は, 他の glycine 抱合物から完全に分離できたが，今回の分析条
件では， $m$-MHA と $p$-MHA の分離は完全ではなかっ た。

2. 尿のクロマトグラム: 正常尿, 暴露尿のクロマト グラムを Fig. 2，3 に示す.

3. 検量線：HA， $m$-MHA の標準液を水および正常 尿に $1 / 1$ の割合で添加したときの HA $(m-\mathrm{MHA})$ 呩 度と peak 高とは, Fig. 4 に示すごとくともに直線関 係にあり，かつ二つの検显線は平行となり，その peak 高の恙は常に正常尿中の HA 量化等しかった。 また， 感度については, $10 \mu \mathrm{g} / \mathrm{ml}$ 以上であれば検出でき，か つ高濃度の場合には水または methanol で希积しても 直線性が浔められた。

以上の結果から，本法は尿中 $\mathrm{HA}, m-\mathrm{MHA}$ の分䧄 定量に十分適用できると考えられる。

4. 正常値：HLC で測定した正常尿中の HA 量（比 車補正後) は，ほぼ対数正規分布を示し，濃度を $\mu \mathrm{g} / \mathrm{ml}$ で表示し対数化した平均值は $2.347(222 \mu \mathrm{g} / \mathrm{ml})$, 標準 偏差 0.256，5\% 玄却限界を上限値とすれば 2.874(748 $\mu \mathrm{g} / \mathrm{ml})$ となった $(n=36)$. また，本法で測定した尿中

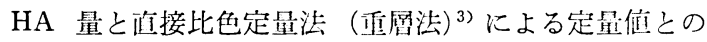
間には，相関係数 $r=0.98(n=21)$ で，高い相関が認 められた。

なお，HA より前に溶出する物所（たとえば INA） の定量を日的とする場合，およびカラムの污染の危惊を 避ける意味からは，内部標準物筫を涯加した抽出法が適 当と考えられるが，これについては次報で述べる。

\section{結 論}

固定相に octadecyl silane を化学絬合させた silica gel を，移動相に methanol/水/酰酸の混液を用いる逆 相クロマトグラフィーにより, 短時間でかつ精度よく, 尿中 HA, $m$-MHA の分離定量拉よび比色法では発色 して定量の妨害となる INA，o-MHA，SA の混在する 尿にも楜用が可能となった。このとき，尿汶刘する抽出 等の特別な前処理は不接で范った。

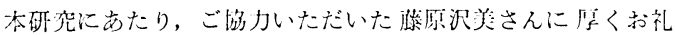
中しあげます。

\section{文 献}

1) Tomokuni, K. and Ogata, M.: Direct colorimetric determination of hippuric acid in urine, Clin. Chem., 18: 349-351, 1972.

2) Ogata, M., Tomokuni, K. and Takatsuka, Y.: Quantitative determination in urine of hippuric acid and $m$-or $p$-methylhippuric acid, metabolites of toluene and $m$ - or $p$-xylene, $\mathrm{Br}$. J. Ind. Med., 26: 330-334, 1969. 


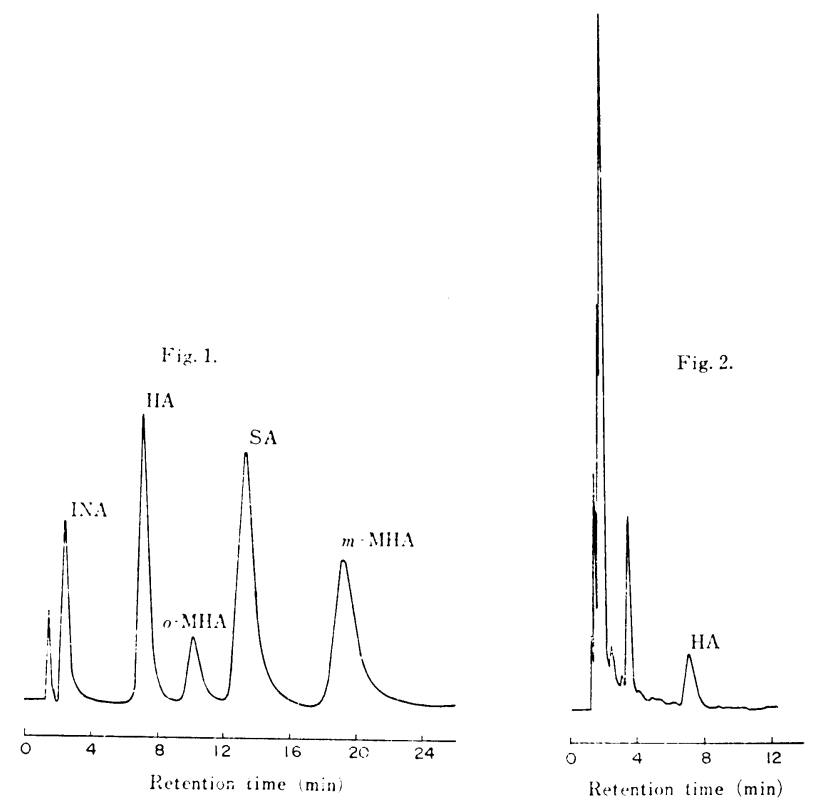

Fig. 3.

Fig. 1. High performance liquid chromatographic separation of standard INA, HA, o-MHA, SA and $m$-MHA.

Fig. 2. Chromatogram of a normal urine specimen.

Fig. 3. Chromatogram of a urine specimen exposed to the mixed vapour of toluene and $m$-xylene.
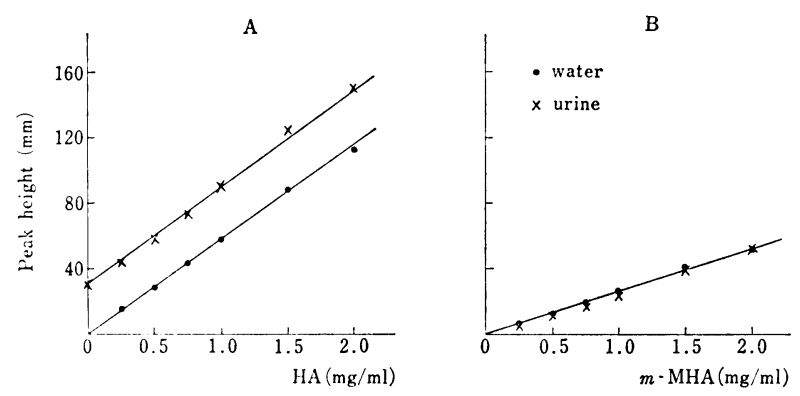

Fig. 4. Calibration lines of HA (A) and $m$-MHA (B) in water and in urine.

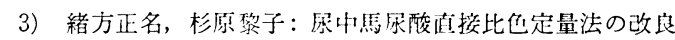
について, 産業医学, 18：40-41， 1976.

緒方正名, 杉原黎子, 吉良尚平

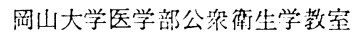

Masana OGata, Reiko Sugihara and Shohei KIRA
Department of Public Health, Okayama University Medical School, Okayama, 700 Japan 昭和 51 年 11 月 22 日受付

通信先：杉原あて, Reprint requests to $\mathrm{R}$. Sugihara 